\title{
RAZVOJ GEOGRAFIJE V SREDNJEM VEKU
}

dr. Darko Ogrin

Oddelek za geografijo, Filozofska fakulteta Univerze v Ljubljani

Aškerčeva 2, SI-1000 Ljubljana

e-pošta: darko.ogrin@ff.uni-lj.si

Strokovni članek

COBISS 1.04

DOI: $10.4312 /$ dela.49.75-94

\section{Izvleček}

V prispevku je prikazana zgodovina geografije v srednjem veku s pomočjo spoznanj iz domače in tuje strokovne literature. Srednji vek ni enotno obdobje v razvoju geografije. Zgodnjega označuje na eni strani zaton antičnih tradicij v krščanskem delu Evrope, na drugi strani pa njihov prevzem in nadgradnja $\mathrm{v}$ islamskem svetu. $\mathrm{V}$ visokem srednjem veku so bila islamska spoznanja med osnovami za geografsko in kartografsko renesanso ter za razvoj v naslednjih stoletjih.

Ključne besede: zgodovina geografije, razvoj geografske misli, zgodnji srednji vek, visoki srednji vek, renesansa

\section{DEVELOPMENT OF GEOGRAPHY IN THE MIDDLE AGES}

\begin{abstract}
The paper presents the history of geography in the Middle Ages through the findings in Slovenian and foreign literature. The Middle Ages were not a uniform period as regards the development of geography. The Early Middle Ages were marked by the decline of Classical Antiquity traditions in the Christian part of Europe on the one hand, but on the other hand they were accepted and upgraded in the Islamic world. In the High Middle Ages, Islamic findings formed the basis for geographic and cartographic renaissance and for the development in the following centuries.
\end{abstract}

Key words: history of geography, development of geographic thought, Early Middle Ages, High Middle Ages, renaissance 


\section{UVOD}

Srednji vek je bil obdobje velikih sprememb. Temeljito se je spremenila politična slika sveta, stari imperiji so propadli, nastali so novi. Spremenile so se družbene in gospodarske razmere, še posebej v Evropi. Zgodovinsko se je začel s propadom zahodnega rimskega cesarstva konec 5. stoletja in je v Evropi trajal do konca 15. stoletja oziroma odkritja Amerike. Z vidika zgodovine geografije nekateri avtorji podaljšujejo srednji vek do industrijske revolucije sredi 18. stoletja (npr. Rana, 2008), kar sovpada s prvimi zametki moderne geografije. Druge členitve zgodovine geografije vključujejo v srednjeveške preglede geografske misli čas od propada zahodnega rimskega cesarstva do okoli leta 1400 (npr. Vresk, 1997), ko je začel razpadati arabski imperij, oziroma do velikih odkritij in odkritja Amerike (npr. Vrišer, 2002; Burke, 2016). Tedaj se je začelo obdobje velikih geografskih odkritij, ki je pomenilo izredno razširitev geografskega obzorja in razcvet geografskega znanja. Po Evropi sta se razširili kulturni gibanji humanizem in renesansa in v ospredje namesto boga postavili človeka in čutno dojemanje sveta. Zaradi podobnosti renesančne miselnosti $\mathrm{z}$ antično je $\mathrm{v}$ tem času naraslo zanimanje za antično kulturo in znanost, tudi za geografijo. Ker je znanje postajalo vse bolj cenjeno, sta humanizem in renesansa postavila tudi temelje znanstveni revoluciji.

Kot srednjeveški razvoj geografije obravnavamo v prispevku čas od konca 5. stoletja do odkritja Amerike leta 1492. Zaradi izjemnega pomena velikih geografskih odkritij za razvoj geografskega znanja in geografije kot znanstvene vede izdvajamo čas med koncem 15. in koncem 18. stoletja kot posebno obdobje v njeni zgodovini.

Pregled razvoja geografije v srednjem veku temelji na kombiniranju spoznanj iz strokovne literature. Med tujimi so osnovo predstavljala dela Martina in Jamesa (1993), Rane (2008), Holt-Jensena (2009) in Cresswella (2013), od domačih smo uporabili neobjavljen Ilešičev tipkopis (Ilešič, 1950), na katerem temelji tudi pregled zgodovine geografije v Vrišerjevem Uvodu v geografijo (Vrišer, 2002). Vsako od uporabljenih del na svoj način, s svojega zornega kota in družbenega konteksta, osvetljuje to oddaljeno obdobje geografske zgodovine. Opazno je, da so nekateri pregledi napisani izrazito (zahodno)evropocentristično, drugi, predvsem avtorji, ki ne izhajajo iz zahodnoevropskega ali angloameriškega prostora (npr. Rana, 2008), pa skušajo bolj uravnoteženo prikazati tudi geografske dosežke v neevropskih (nekrščanskih) deželah, kot na primer arabskih in kitajskih. Nekateri vključujejo tudi dosežke Normanov (npr. Holt-Jensen, 2009) in Rusov (Nikolić, 1977), ki so pogosto spregledani. Nekateri pregledi se bolj osredotočajo na razvoj družbene geografije (Burke, 2016), drugi so z vidika geografske stroke bolj celostno zasnovani (Martin, James, 1993; Rana, 2008). Prikaz v nadaljevanju je samo eden od možnih pogledov na razvoj geografije $\mathrm{v}$ srednjem veku, kjer sem na osnovi različnega gradiva poskušal narediti uravnoteženo sintezo različnih interpretacij razvoja geografije v srednjem veku v evropskem prostoru.

\section{ZGODNJI SREDNJIVEK}

Zgodnji srednji vek je čas od propada centralistično urejenega Rimskega imperija in vpadov barbarskih ljudstev do okoli leta 1100. Na družbeni, gospodarski in kulturni 
Slika 1: Rekonstrukcija karte sveta Pomponija Mele (Millerjeva rekonstrukcija ..., 2018). Figure 1: Reconstruction of Pomponius Mela's world map (Millerjeva rekonstrukcija ..., 2018).

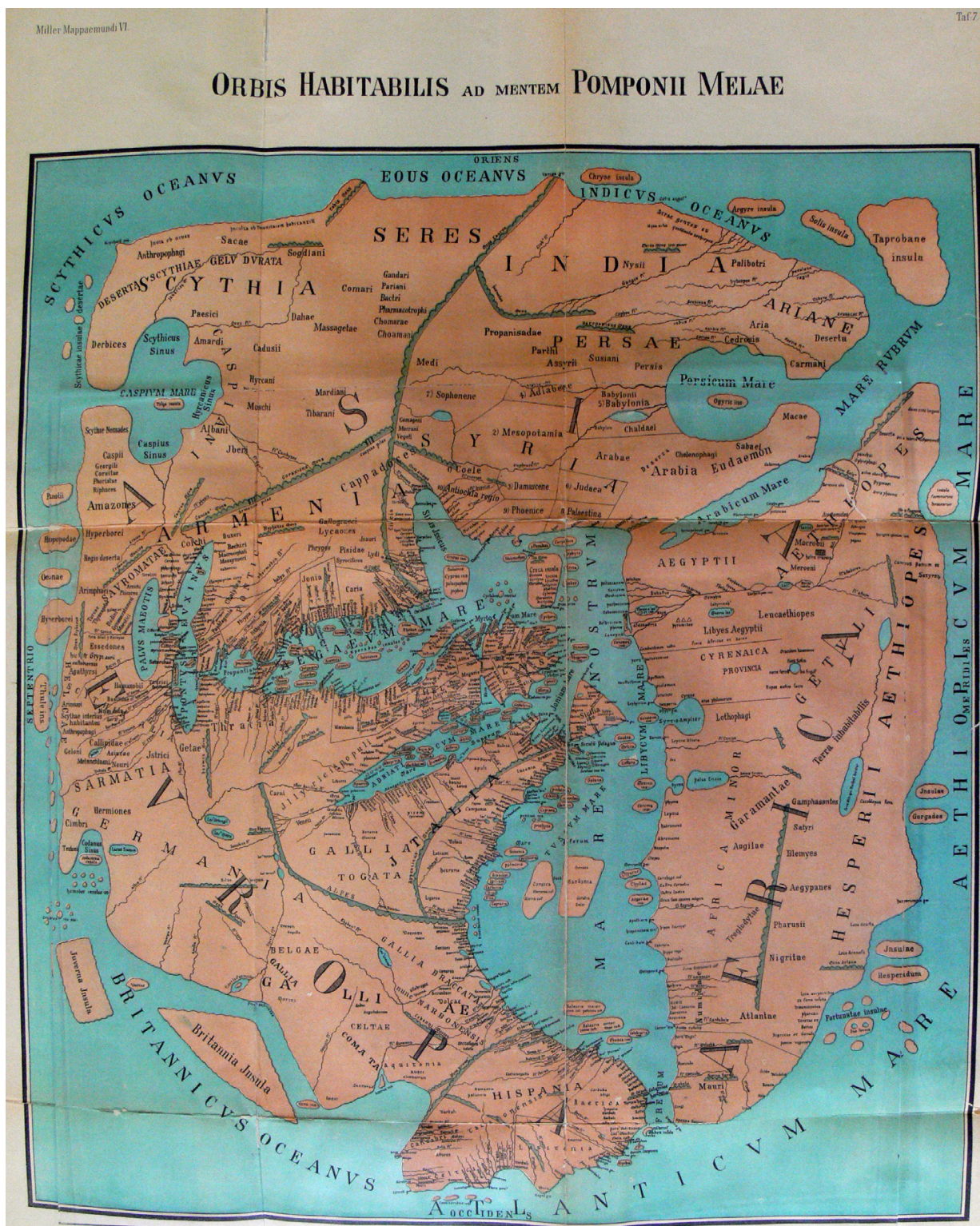


razvoj ter način mišljenja je imelo velik vpliv krščanstvo, ki so ga postopoma prevzeli tudi tako imenovani barbari. Za ta čas je značilna pozaba večine antičnih kulturnih in znanstvenih pogledov na svet in v geografiji njihova zamenjava $\mathrm{z}$ nekritičnimi kozmografijami (splošnimi opisi vesolja, vključno z Zemljo), ki so večinoma temeljile na svetih spisih. Potovanj in raziskovanj je bilo zaradi politične nestabilnosti zelo malo. Krščanstvo plovbe ni spodbujalo, saj starozavezno izročilo morju ni bilo naklonjeno, prav tako ne »narodom z morja« (Matvejević, 2008). Še največ so k poznavanju značilnosti posameznih dežel in narodov prispevala misijonarska potovanja zaradi širjenja krščanstva in romanja v svete kraje.

Največ intelektualnega življenja je bilo za samostanskimi zidovi. Učenjaki v samostanih niso raziskovali Zemlje s pomočjo neposrednih opazovanj ali eksperimentiranja, ampak so zbirali informacije iz različnih pisnih virov. Glavni cilj njihovega dela je bil uskladiti geografske ideje iz teh virov z zapisi v Svetem pismu, še posebej v Genezi. Vsebine, ki se niso skladale s Svetim pismom, so bile prezrte. V zgodnjem srednjem veku so imeli evropski učenjaki dostop le do latinskih virov, kasneje se jih je nekaj naučilo tudi arabsko. Grški viri, ki dotlej niso bili prevedeni, so bili nepoznani.

Le maloštevilni geografski viri so bili dostopni v latinščini. Martin in James (1993) omenjata Pomponija Melo (lat. Pomponius Mela, ? - ok. 45 n. št.) in Plinija Starejšega (lat. Gaius Plinius Maior, ok. 23/24-79 n. št.) iz 1. stol. n. št. Oba sta v svojih delih uporabljala tudi grške vire, tako da so imeli srednjeveški učenjaki posredno vpogled tudi v nekatera grška razmišljanja. Po mnenju Hriberška (2013) je Plinijevo Naravoslovje kot znanstveni priročnik doseglo v srednjem veku svoj vrhunec in zasenčilo vse druge antične enciklopedije. Bilo je del meniške kulture, vsi pomembnejši samostani so imeli vsaj eno knjigo. V skriptorijih so ga redno prepisovali, bilo je vir idej za ilustracije in iluminacije ter osnova za srednjeveške opise sveta (kozmografije).

Srednjeveško intelektualno okolje ni bilo naklonjeno kritičnemu znanstvenemu delu. Marcijan Kapela (lat. Martianus Capella, 360-428) in Ambrozij Teodozij Makrobij (lat. Ambrosius Theodosius Macrobius, 370-430) sta sicer že v 5. stoletju prevedla Platona v latinščino, tako da so imeli učenjaki vpogled tudi v grška razmišljanja o okrogli obliki Zemlje, vendar je prevladalo naziranje o ravni Zemlji (Martin, James, 1993). Antične predstave o svetu so bile preoblikovane v skladu s cerkvenim naukom. Zemljo so razumeli kot okrogel disk z Jeruzalemom v središču. Tako razmišljanje ni bilo vzpodbudno za razvoj kartografije. Antična tradicija izdelovanja zemljevidov je zamrla. Risali so estetske, vendar nestrokovno izdelane karte. Najbolj razširjen tip zemljevida tistega časa so bile t. i. orbis-terrarum karte oziroma $\mathrm{O}-\mathrm{T}$ (tudi $\mathrm{T}-\mathrm{O}$ ) karte. Upodabljanje Zemlje, dejansko Sredozemlja s sosednjimi območji, kot svetovnega kolesa je prevladovalo vse do renesanse. »O $\mathrm{O}$ ( pri tovrstnih zemljevidih ponazarja ocean, ki obliva kopno, »T« pa morje, kjer je deblo T-ja Sredozemsko morje, zgornji del pa Črno morje z reko Don in na drugi strani Nil. V središču karte in hkrati poseljenega sveta je bil Jeruzalem, na vzhodu, na skrajnem robu poseljenega sveta, pa raj (Rana, 2008; Burke, 2016). 
Slika 2: Rekonstrukcija srednjeveške O-T karte sveta (O-T karta sveta, 2018).

Figure 2: Reconstruction of mediaeval T-and-O world map (O-T karta sveta, 2018).

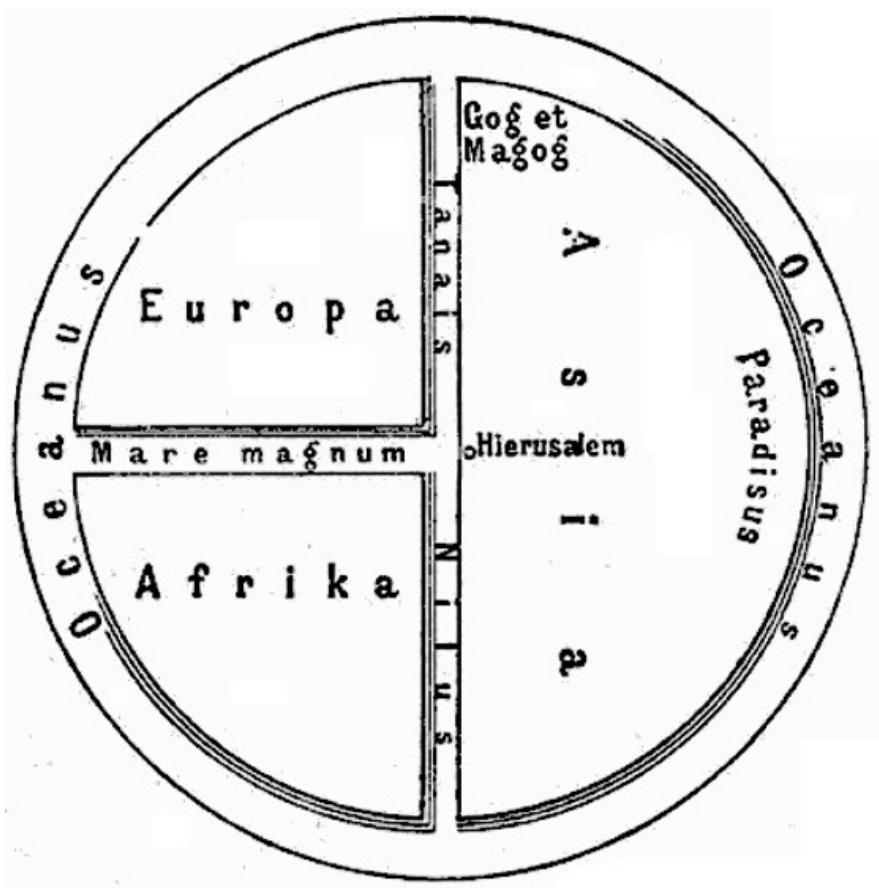

\section{I Geografsko obzorje v zgodnjem srednjem veku}

Za stare Grke je geografsko obzorje (meje sveta, ki so bile poznane vsaj učenjakom in trgovcem) segalo od reke Ind na vzhodu do Atlantskega oceana na zahodu, na severu od step severno od Črnega morja do Etiopije na jugu. Za Rimljane je obsegalo vsa območja, ki so bila pod njihovo upravo. Po propadu imperija se je močno skrčilo. Večinoma so bila ljudem znana le območja in kraji v njihovi neposredni okolici. Svet onstran teh meja je bil po njihovem prepričanju poseljen z raznimi prikaznimi, ki so si jih izmislili brez realnih osnov. V krščanskem delu Evrope je v tem času beseda geografija izginila iz besednjaka (Martin, James, 1993). Ni pa popolnoma izginilo geografsko udejstvovanje v najširšem pomenu te besede.

Krščanski del Evrope je imel v tem času pomanjkljive predstave o svetu z veliko nejasnostmi o obsegu sveta in razdaljami med kraji. Potovanj in plovb je bilo malo, tisti, ki so jih zanimale dimenzije geografskega obzorja in svet okoli njih, pa po mnenju Martina in Jamesa (1993) niso imeli teoretičnega znanja, s katerim bi si pomagali pri razlaganju naravnih in družbenih pojavov. Zato so tudi opisi teh potovanj brez večje strokovne teže. Tak je na primer zapis potovanja sv. Silvije iz Akvitanije (lat. S. Silvia Aqvitana, 330-406), ki je po kopnem potovala v Jeruzalem, nato še v Egipt, Arabijo in 
Mezopotamijo. Zaradi opisa romanja v svete dežele, ki je nastal okoli leta 385, lahko štejemo Silvijo iz Akvitanije za eno prvih geografinj. Ker je število romarjev v svete kraje naraščalo, so izdelovali vodnike, s katerimi so si romarji pomagali na poti. To so bili predhodniki današnjih turističnih vodnikov, ki so v širšem smislu tudi del geografske strokovne literature.

Zaradi muslimanske zasedbe so v 9. stoletju postajale ustaljene poti romarjev do Jeruzalema prek današnje Turčije in Sirije vse bolj težavne in nevarne. Zaradi preprečitve širjenja islamskega vpliva, gospodarskih razlogov in tudi povrnitve nadzora nad Sveto deželo je krščanska Evropa organizirala niz vojaških pohodov. Med letoma 1096 in 1270 je bilo osem križarskih pohodov; nekateri so potekali po kopnem, drugi po morju. $\mathrm{Ob}$ osmih uradnih pohodih so bile še številne druge vojaške akcije. Med eno od njih je leta 1365 ponovno pogorela Aleksandrijska knjižnica, ki je od ustanovitve v začetku 3. stol. pr. n. št. doživela več požarov in delnih uničenj, med katerimi je bilo izgubljenih veliko del grških učenjakov. Križarski pohodi so vplivali tako na krščanski kot muslimanski svet. V Evropo so prihajale informacije o deželah na vzhodu, tudi razburljive zgodbe o nenavadnih ljudeh in pokrajinah onstran evropskega geografskega obzorja. Križarji so prinašali razno blago in inovacije, ena od njih je bila na primer mlin na veter (Martin, James, 1993). Muslimani so kmalu po osvojitvi Bližnjega vzhoda zaprli trgovske poti, po katerih so beneški in genovski trgovci vzdrževali stike z vzhodom, ter postali monopolistični posredniki in s tem bogato služili.

Širok geografski horizont so imela v srednjem veku ljudstva na severu Evrope. Normani niso poznali ne arabskih, ne grških mislecev, prav tako niso vedeli, da so veljale njihove dežele že od antičnih časov naprej kot neprimerne za poselitev. Normanske raziskovalne, roparske in trgovske ekspedicije so segale daleč na vzhod v osrednji del današnje Rusije, čez Rusijo so prišli tudi do Bizanca, ki pa ga niso osvojili. Bili so pogumni pomorščaki, ki so se uspešno spopadali z Atlantikom. Ugodne podnebne in oceanografske razmere $\mathrm{v}$ tako imenovanem srednjeveškem toplem obdobju (Ogrin, 2005) so jim omogočile raziskovalne in kolonizacijske plovbe po severnem Atlantiku. Naselili so se na Irskem, kjer so prej že živeli Irci, kot prvi pa so poselili Islandijo, okoli leta 1000 so pripluli do Grenlandije in, kakor kaže, tudi do Severne Amerike. Sage o teh dosežkih so se prenašale z ustnim izročilom, zapisane so bile šele 100-200 let po teh dogodkih na od Evrope izolirani Islandiji. Da so bili Normani v Ameriki več kot 400 let pred Kolumbom, so dokazala arheološka raziskovanja na Novi Fundlandiji (Holt-Jensen, 2009). Normanska kolonizacija na Novi Fundlandiji se ni obdržala, prav tako ne na Grenlandiji, saj jo je po 500 letih prekinila mala ledena doba z zelo ostrim podnebjem in epidemijo kuge.

Medtem ko je učenost v srednjeveški Evropi stagnirala, je cvetela na Kitajskem. Med 2. stol. pr. n. št. in 15. stoletjem je bila Kitajska kulturno zelo napredna država. Znanost je bila visoko razvita, Kitajci so izstopali po uporabi strokovnih spoznanj v praktične namene. Tudi njihova geografija je bila precej bolj razvita od evropske. Kitajci so raziskali Evropo in Indijo davno preden so Evropejci spoznali vzhod. Izdelovali so precej natančne zemljevide svoje države in sosednjih dežel, pri čemer so uporabljali geografske koordinate, pri merjenju razdalj pa so si pomagali z metodo triangulacije. Ko je Marco Polo (1254-1322) opisal svojo pot in bivanje na Kitajskem, kjer je predstavil tudi visoko 
raven kitajske učenosti, velik del Evrope njegovim zapisom ni verjel in jih je dojemal kot izmišljeno avanturo.

\section{VZPON ISLAMSKIH ZNANSTVENIH SREDIŠČ IN VISOKI SREDNJIVEK}

\section{I Geografija v islamskem svetu}

Medtem ko je Evropa intelektualno stagnirala, je velik napredek naredil islamski svet, ki je postal most med antično civilizacijo in modernim svetom. Islamska civilizacija je cenila ustvarjanje in širjenje znanja, kar je pripeljalo do pomembnih znanstvenih dosežkov. Vzpon islamskih znanstvenih središč je pomenil konec recesije znanosti in ponovni razvoj znanstvenih pristopov v geografiji.

Islam je nastal v 7. stoletju na Arabskem polotoku. Nova religija je v kratkem času združila pred tem sovražna arabska plemena in nastal je velik imperij s civilizacijo, ki je bila med najnaprednejšimi v tistem času. Novo religijo je sprejel skoraj ves tedanji arabski svet in postal enotna država še pred smrtjo ustanovitelja islama, preroka Mohameda leta 632. Mohameda so nasledili kalifi, ki so osvojili in islamizirali Sirijo, Iran, del osrednje Azije in Egipt, pozneje še Severno Afriko in večji del Španije (Svetovna zgodovina ..., 1976). Ob širitvi imperija v Sirijo, Perzijo in Baktrijo, antično pokrajino v osrednji Aziji med Hindukušem in zgornjim tokom Amu Darje, so prišli tudi v neposreden stik z grško kulturo, ki je tu še živela, in prevzeli njene dosežke.

Arabci v obdobju pred islamizacijo niso imeli razvite pisave, prav tako ne znanosti in umetnosti. Razvoj se je začel vzporedno z islamom. Znanje so iskali povsod, kjer so ga lahko dobili. Leta 762 je dinastija Abasidov ustanovila Bagdad, ki je za več kot 100 let postal intelektualno središče sveta. Ustanovljena je bila tudi univerza, ki je vabila učenjake z vsega sveta, da bi poučevali in pomagali arabskim učenjakom pri prevajanju grških, latinskih, perzijskih in sanskrtskih del v arabščino. Islamski svet je prevzel grške, rimske, perzijske in indijske geografske ideje ter na njihovi osnovi začel z lastnimi opazovanji in raziskovanji. Razvili so nove teorije in koncepte, napisali veliko knjig z različnih področij geografije in sorodnih ved ter razširili to znanje do dežel ob obalah Atlantika in Indijskega oceana.

Ustanovitev obsežnega imperija je omogočila združitev intelektualnih in znanstvenih tradicij različnih civilizacij, od vzhodnih do zahodnih. Razen Bagdada so postala pomembna intelektualna središča islamskega sveta še Jeruzalem, Kairo, Damask, Širaz v Perziji, Fez v Maroku, Timbuktu v Maliju in Toledo v Španiji. K razvoju geografskega znanja $\mathrm{v}$ velikem in raznolikem imperiju, ki je komuniciral po dobro razvitem cestnem omrežju kot dediščini Rimskega imperija, je veliko pripomogla tudi dobro razvita trgovina. Islamski trgovci so trgovali s številnimi deželami in prinašali informacije, s katerimi so dopolnjevali antična znanja, tudi Ptolemajeve zemljevide.

Prispevek islamskih učenjakov k razvoju geografije je zelo velik in sega na različna področja; od planetarne, fizične, družbene in regionalne geografije do kartografije. 
Povzetek islamskega prispevka k napredku geografije je narejen po Rani (2008). Osnovna planetarna in matematičnogeografska znanja so prevzeli od starih Grkov, predvsem iz del Aristotela in Ptolemaja. Sprejeli in nadgradili so grška spoznanja o obliki in velikosti Zemlje. V zgodnjem obdobju so razlagali, da je Zemlja središče vesolja in okoli nje kroži sedem planetov. Vsak planet naj bi imel svojo sfero (nebo), zvezde pa naj bi sestavljale osmo, najvišjo sfero. Večkrat so izračunali obseg Zemlje, npr. Al Batani (858-929; Abū 'Abd Allāh Muḥammad ibn Jābir ibn Sinān al-Raqqī al-Ḥarrān̄̄ aṣ-Ṣābi' al-Battān̄i), ki je naračunal višjo vrednost kot Ptolemaj. Al Batani je zelo natančno določil nagnjenost ekliptične ravnine, dolžino letnih časov in Sončevega leta. Njegovo astronomsko in matematično znanje je bilo v renesančni Evropi zelo vplivno. Eratostenovo metodo izračuna obsega Zemlje je izpopolnil Al Biruni (973-1048; Abū Rayḥān Muḥammad ibn Aḥmad Al-Bīrūnī). Njegov izračun, 39.833 km (Eratosten: $39.672 \mathrm{~km}$ ), je bil v zahodnem svetu izboljšan šele v 16. stoletju.

Dobro matematično znanje, vpeljava indijskih številk (danes jih poznamo kot arabske, saj so jih Arabci razširili po svetu) in števila 0 ter izpopolnjena trigonometrija so omogočili tudi lažje in natančnejše računanje dimenzij na Zemljinem površju. Niso pa Arabci bistveno nadgradili antičnega kartografskega znanja in tehnik izdelovanja zemljevidov. Pomorske in druge zemljevide so izdelovali s pomočjo valjnih (cilindričnih) projekcij. Verjetno najbolj poznan arabski kartografski izdelek je Tabula Rogeriana, zemljevid sveta, ki ga je leta 1154 izdelal Al Idrisi (1100-1165 ali 1166; Abū 'abd Allāh Muḥammad Ibn Muḥammad Ibn 'abd Allāh Ibn Idrīs Al-ḥammūdī Al-ḥasanī Al-idrīsī; latinizirano: Dreses) za Rogerja II., normanskega kralja Sicilije. Zemljevid je kar tri stoletja veljal za najbolj natančno karto sveta. Na njem je 2500 geografskih imen, prikazuje Evropo, Azijo in severni del Afrike, orientiran pa je tako, da je sever spodaj.

Slika 3: Al Idrisijeva Tabula Rogeriana (kartofilska zbirka: D. Ogrin).

Figure 3: Al-Idrisi's Tabula Rogeriana (cartophilic collection: D. Ogrin).

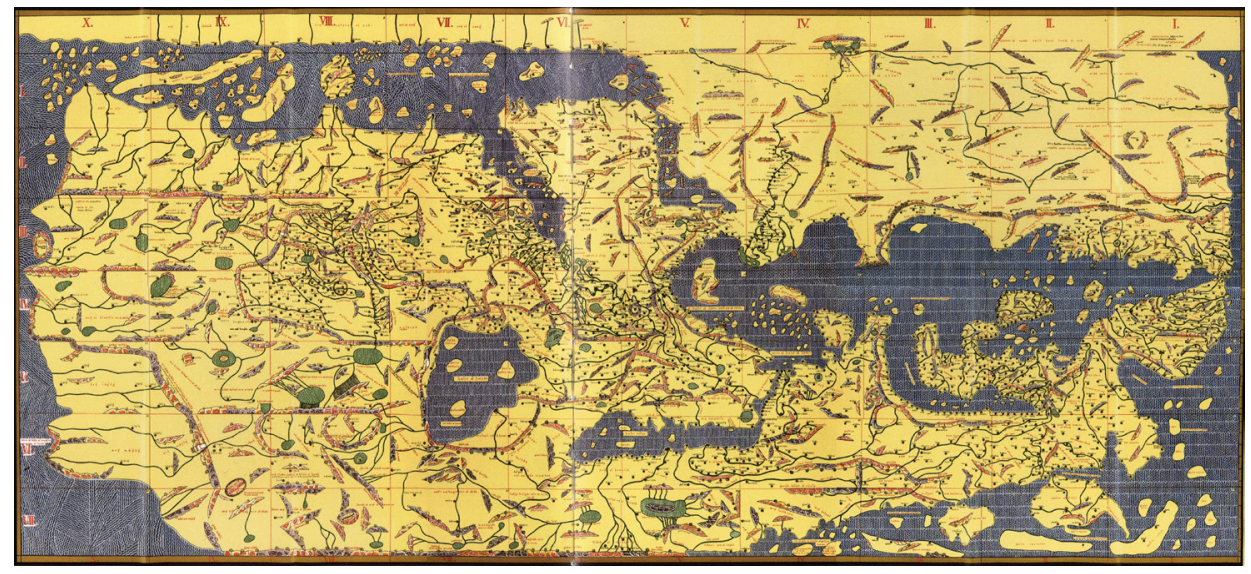


Na področju fizične geografije je arabska geografija zelo napredovala pri poznavanju geomorfoloških, oceanografskih in še posebej klimatoloških pojavov in procesov. Ibn Sina (okoli 980-1037; Abu Ali Husain ibn Abdullah Ibn-e Sina; latinizirano: Avicenna) je raziskoval preoblikovalne procese Zemljinega površja, erozijo in denudacijo. Postavil je tezo, da reke znižujejo gorovja in da so najvišji vrhovi zgrajeni iz erozijsko bolj odpornih kamnin. S fluvialnimi procesi in procesi odlaganja sedimentov se je na primeru Himalaje ukvarjal Al Biruni. Študiral je zaobljenost prodnikov in jo razlagal kot posledico rečnega transporta. Ugotovil je, da je gradivo, ki ga reke odložijo bližje gorovjem, bolj grobo od gradiva, ki ga odložijo dlje od povirnih delov.

Različni islamski učenjaki in pomorci so se ukvarjali s plimovanjem. Razlagali so ga z gravitacijskim delovanjem Sonca in Lune. Al Idrisi je popravil napačne predstave o Indijskem oceanu in Kaspijskem morju. Dokazoval je, da je Indijski ocean odprto morje, Kaspijsko morje pa jezero.

Največji napredek so naredili islamski učenjaki pri proučevanju podnebja. Razložili so periodičnost monsunske cirkulacije in vpeljali termin monsun (mausim). Indijski monsun je podrobno proučeval Al Masudi (888-957; Abu al-Hasan Ali ibn al-Husajn al-Masudi). Al Balkhi (850-934; Abu Zayd Ahmed ibn Sahl Balkhi) je leta 921 izdelal prvi klimatski atlas sveta (Kitabul Ashkal). Klimatske podatke zanj je zbral s pomočjo islamskih popotnikov in trgovcev. Leta 985 je Al Maqdisi (946-991; tudi Al Muqaddasi, El Mukaddasi; Muḥammad ibn Aḥmad Shams al-Dīn al-Maqdisī) svet razdelil na 14 podnebnih območij. Trdil je, da se podnebje spreminja z geografsko širino in tudi v smeri vzhod-zahod ter da so podnebne razlike med severno in južno poloblo posledica večjega deleža kopna na severni polobli.

Družbenogeografske vsebine so prisotne predvsem v delih Ibn Khalduna (1332-1406; Abū Zayd 'Abd ar-Raḥmān ibn Muḥammad ibn Khaldūn al-Hậ̣ramī I), ki ga štejejo za predhodnika sodobnega zgodovinopisja, sociologije, ekonomije in demografije. V delu Muqaddimah (Uvod) je opisal človeško družbo z več plati. Na znanstven način je poskušal razložiti tudi odnos med človekom in njegovim okoljem. Opiral se je na klimatski determinizem. Trdil je, da ima podnebje zelo velik vpliv na značaj ljudi, na barvo kože in značilnosti človeških bivališč.

Zelo velik je arabski prispevek k poznavanju sveta. Izstopajo dela Al Idrisija in Ibn Battute (1304-1378; 'Abū 'Abd al-Lāh Muḥammad ibn 'Abd al-Lāh 1-Lawātī ț-Ṭanğî ibn Bațūtah). Al Idrisi je bil eden vodilnih učenjakov 12. stoletja, ki je deloval v Cordobi in govoril arabsko, perzijsko, latinsko, grško in špansko. Prepotoval je Španijo, Portugalsko, Francijo, Anglijo, Sicilijo, Maroko, Sirijo, Malo Azijo in tudi nekatere dežele v notranjosti Afrike. V knjigi Kitab nuzhat al-mushtaq fi'khtiraq al-'afaq (Knjiga prijetnih potovanj $v$ oddaljene dežele), v literaturi je omenjena tudi kot Al-Kitab al-Rujari (Rogerjeva knjiga), je opisal svet v luči naravnih, gospodarskih in kulturnih razmer. Uporabil je antične in arabske vire, za Severno Evropo pa tudi informacije, ki jih je na Siciliji dobil od Normanov. Delo je geografska enciklopedija tedaj poznanega sveta, ki je na zahod segal do Atlantika, na vzhod do Japonske, na sever do Sibirije, na jug pa južno od ekvatorja v Afriki. Knjiga je bila prevedena $v$ latinščino in bila zelo vplivna več stoletij. 
Za enega največjih popotnikov vseh časov velja Ibn Battuta, ki je prepotoval večji del južne in osrednje Azije ter domnevno obiskal Kitajsko 60 let pred Marcom Polom. Prepotoval je saharski del Afrike, plul po Indijskem oceanu in ob vzhodni obali Afrike prišel do $10^{\circ}$ južne geografske širine. Ugotovil je, da ob ekvatorju živijo številna ljudstva in tako ovrgel antično teorijo, da je ob ekvatorju prevroče, da bi lahko tam živeli ljudje. Poročilo o njegovem več kot 30-letnem potovanju po svetu je strnjeno v delu Rihla (Popotovanje), natančen prevod knjige je Poklon tistim, ki preudarjajo čudeže dežel in čudovitih potovanj (slovenska izdaja oziroma izbor besedil: Ibn Battuta, 2016). Knjiga, ki jo je po zaključku potovanj po takratnem islamskem svetu in sosednjih deželah narekoval po spominu, predstavlja pomemben vir informacij o večjem delu sveta v srednjem veku. Motivi za Battutova potovanja so bili trije: romanje v sveto mesto Meka, želja po spoznavanju novih krajev in dežel ter neizpodbitna želja po znanju (Ibn Battuta, 2016, str. 16).

Slika 4: Dežele, ki jih je prepotoval Ibn Battuta (prirejeno po: Ibn Battuta, 2011; Travels of Ibn Battuta, WorldMap, 2015).

Figure 4: Countries travelled by Ibn Battuta (adapted from: Ibn Battuta, 2011; Travels of Ibn Battuta, WorldMap, 2015).

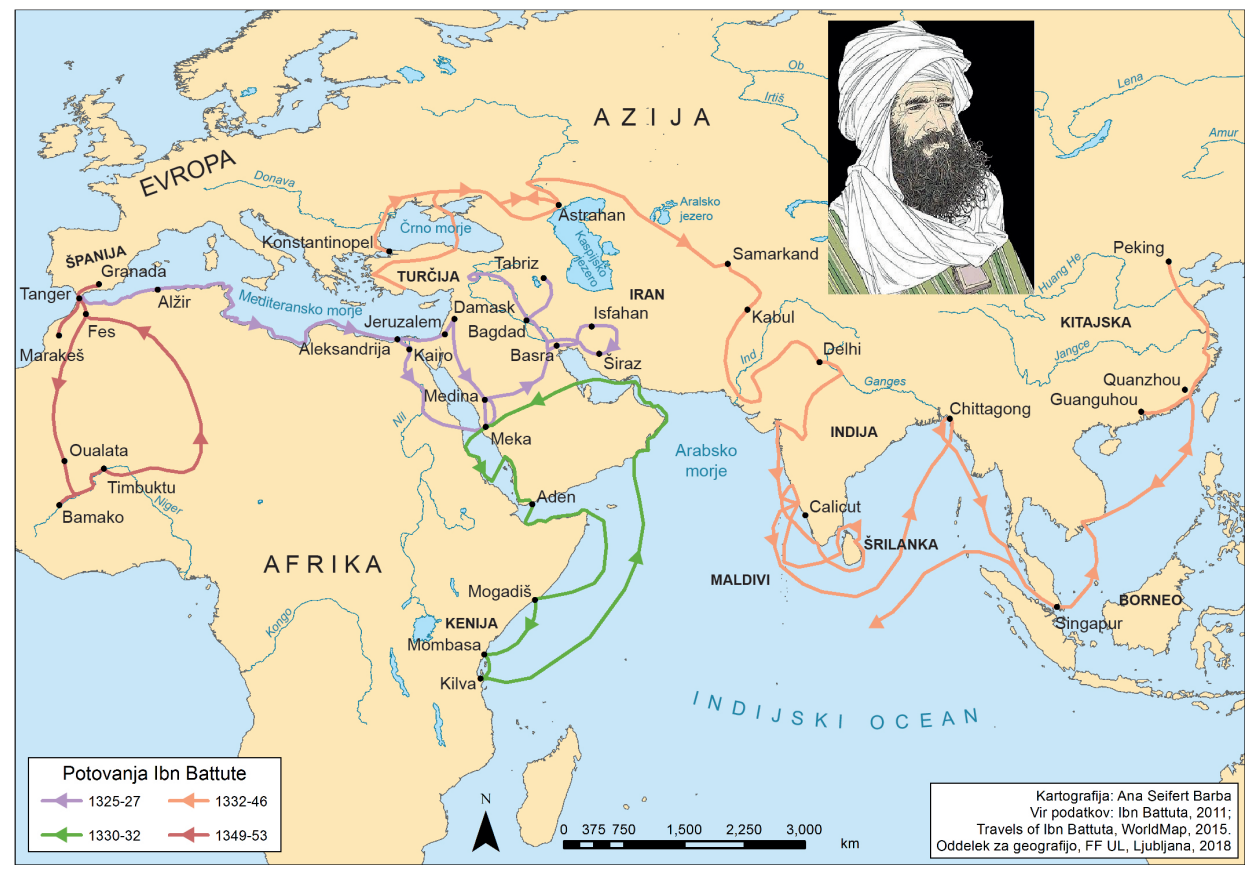

Čeprav je okoli leta 1400 začel islamski imperij razpadati in z njim tudi islamska znanstvena misel, je bilo delo islamskih učenjakov zelo pomembno za razvoj evropske znanosti in tudi geografije. Pri življenju so obdržali grške znanstvene dosežke, ki so z 
njihovo pomočjo prišli v Evropo in postali ena od osnov renesanse. Arabski učenjaki so veliko prispevali k boljšemu poznavanju in razumevanju številnih fizično- in družbenogeografskih pojavov na Zemljinem površju in pripomogli k bolj realistični podobi sveta. Napisali so obsežna dela o tedaj poznanem svetu, ki so postala zelo pomemben vir informacij v času velikih geografskih odkritij.

\subsection{Geografija v krščanskem delu Evrope v visokem srednjem veku}

V visokem srednjem veku se je avtoriteta Cerkve v znanosti začela krhati. Zamajali so jo učenjaki, ki so zbrali dovolj poguma za soočanje znanstvenih argumentov z argumenti cerkvenih avtoritet. Trdili so, da če nam je Bog dal razum, ni nobenega razloga, da ga ne bi tudi uporabljali. Eden prvih, ki je trdil, da svet urejajo naravni zakoni in ne božja volja, je bil Viljem iz Conchisa (lat. Guillelmus de Conchis, fr. Guillaume de Conches; ok. 1090-ok. 1154). Njegovo delo De philosophia mundi sestavljajo štiri knjige, ki pokrivajo fiziko, astronomijo, geografijo, meteorologijo in medicino. Med drugim je avtor ideje, da se ozračje ogreva od površja in da oblaki nastanejo z ohlajanjem zraka.

Tudi znotraj cerkve so se začeli uveljavljati naprednejši znanstveni nazori. Angleški škof Robert Grosseteste (ok. 1175-1253), ki se je naučil arabščine in imel zato dostop do večjega števila virov kakor njegovi sodobniki, ki so obvladali samo latinščino, je zaslužen za negiranje antične trditve, da je vroči pas ob ekvatorju neprimeren za poselitev. Grosseteste je bil učitelj Rogerja Bacona (ok.1214-1294), začetnika angleške znanosti, ki se je v svojem delu Opus Majus (Glavno delo) ukvarja tudi z geografijo. V glavnem je prevzemal antične poglede, nekatere tudi nekritično nadgradil, npr. o simetričnosti severne in južne poloble in do katere geografske dolžine sega Azija. Trdil je, da je Zemlja okrogla in da jo je možno objadrati (Ilešič, 1950). Njegova dela je papež prepovedal, sam pa je bil leta 1278 obsojen na dolgoletno ječo.

Glavna avtoriteta glede astronomskih znanj je bil v srednjem veku Ptolemaj. Njegovo delo Megale Syntaxis (v arabščini Almagest, veliko delo o astronomiji) je bilo iz arabščine prevedeno v latinščino leta 1175. Pod vplivom Almagesta je geocentrična razlaga vesolja obveljala za več stoletij.

$\mathrm{V}$ 12. stoletju so bila v latinščino prevedena tudi Aristotelova dela. Z njimi je prišel v Evropo koncept okoljskega determinizma. V srednjeveški miselnosti so se zelo uveljavile grške ideje o spreminjanju značilnosti poselitve z geografsko širino, tudi ideja, da so ljudje, ki živijo na meji poselitve v vročem pasu, temnopolti, če pa se preselijo v zmerno topli pas, pa sčasoma dobijo svetlo polt. Pri prevajanju in razlagi antičnih del o spreminjanju površja so v srednjem veku zelo poudarjali pomen naravnih katastrof, kot so potresi, poplave in vulkanski izbruhi, zanemarjali ali povsem izpustili so razlage spreminjanja površja s počasnimi in manj opaznimi procesi, kot sta rečna erozija in akumulacija gradiva (Martin, James, 1993).

Velikega pomena za razvoj znanosti in tudi geografije proti koncu srednjega veka sta bili kulturni gibanji humanizem in renesansa. Humanizem je kulturno-idejna smer, ki je v ospredje postavljala človeka in ne Boga, ki ga je poudarjal srednji vek. Začel 
se je v mestih severne Italije in Flandrije, kjer so se oblikovale nove, merkantilistične oblike družbenih odnosov, ki so temeljili na trgovanju. Trgovali so predvsem z luksuznimi dobrinami, kot so svila in začimbe, in vzpostavili povezave med mesti, kot sta Amsterdam in Benetke, z Jugovzhodno Azijo. Nastal je močan družbeni razred trgovcev-meščanov, ki je razpolagal s kapitalom in bil pretežno neodvisen od cerkvenih struktur. Humanisti so se zgledovali po antiki, ki je prav tako poudarjala individualizem, senzualizem (čutno dojemanje sveta), esteticizem (poudarjanje lepote) in cenila znanje. Zelo se je povečalo zanimanje za kulturo starih Grkov in Rimljanov, ponovno je bila odkrita antična znanost, tudi zato, ker se je ohranila v islamskem svetu (Svetovna zgodovina, 1976).

Z vidika razvoja geografije sta pomembni leti 1410, ko so bile v latinščino prevedene kopije Ptolemajeve geografije, in 1450, ko je bila po ukazu papeža v latinščino prevedena Strabonova geografija. Znanje ter poznavanje sveta in vesolja, zaobjeto v teh delih, je bilo po Creswellu (2013) tudi eden od temeljev humanizma. Oba prevoda sta povečala zanimanje za geografijo, geografsko znanje pa je veliko pripomoglo k raziskovanju in izkoriščanju novih in manj poznanih ozemelj. Meščanstvo je geografska znanja potrebovalo za uspešno trgovanje, za spoznavanje dežel, s katerimi so trgovali, in obvladovanje kolonij, potrebovalo je izpopolnjena znanja o navigaciji in natančne zemljevide. Začele so nastajati izpopolnjene verzije Ptolemajevih kart, kasneje tudi karte z izboljšanimi kartografskimi projekcijami in koordinatnim sistemom. Pod vplivom Ptolemaja, ki je za del geografije štel tudi horografijo, to je opise in upodobitve (vključno s kartografskimi) krajev in mest, je renesansa vzpodbujala nastanek tudi tovrstnih del. Še pred tem, ob koncu 13. stoletja, so začeli nastajati tudi prvi izolarji (ital. isola - otok), dela, ki združujejo geografske, zgodovinske, kulturološke, kartografske, slikarske ipd. predstavitve otokov, ki so bili pomorcem v pomoč pri plovbi (Matvejević, 2008).

Velik vpliv na geografska odkritja, ki so se začela v drugi polovici 15. stoletja, je imel francoski kardinal Pierre d'Ailly (1351-1420). Čeprav je uporabljal samo latinske vire, predstavlja njegova kozmografija Tractatus de Imagine Mundi (Podobe sveta) kakovosten zbirnik spoznanj o svetu v njegovem času. Bil je med prvimi, ki je v drugi izdaji knjige iz leta 1414 uporabil spoznanja iz latinskega prevoda Ptolemajeve geografije (izšel 1410), ko je izšla tudi prva izdaja Imaga Mundi. V delu povzema različna mnenja o možnosti življenja v vročem pasu, oporeka Ptolemajevemu stališču, da je Indijski ocean zaprto morje in se sklicuje na več poročil, ki trdijo, da ima Indijski ocean ob južnemu delu Afrike stik z Atlantikom. Te trditve so imele velik vpliv na portugalske geografe in pomorščake, ki so kmalu začeli iskati morsko pot v Indijo okoli Afrike, da bi se izognili islamskim ozemljem. D'Ailly je prevzel tudi zmoto o manjšem obsegu Zemlje in je bil med prvimi, ki je trdil, da je mogoče priti v Indijo s plovbo proti zahodu, kar je vplivalo na Kolumbovo odločitev. Kozmografija Tractatus de Imagine Mundi je bila v 15. stoletju zelo popularno in razširjeno delo, tudi po zaslugi iznajdbe tiska sredi stoletja (Martin, James, 1993). V 15. stoletju je k boljšemu poznavanju sveta prispeval tudi papež Pij II. (Aeneas Silvius), ki je med leti 1458 in 1464 napisal knjigo o Evropi in Aziji. 
Slika 5: Kardinal Pierre D'Ailly (kartofilska zbirka: D. Ogrin).

Figure 5: Cardinal Pierre D'Ailly (cartophilic collection: D. Ogrin).

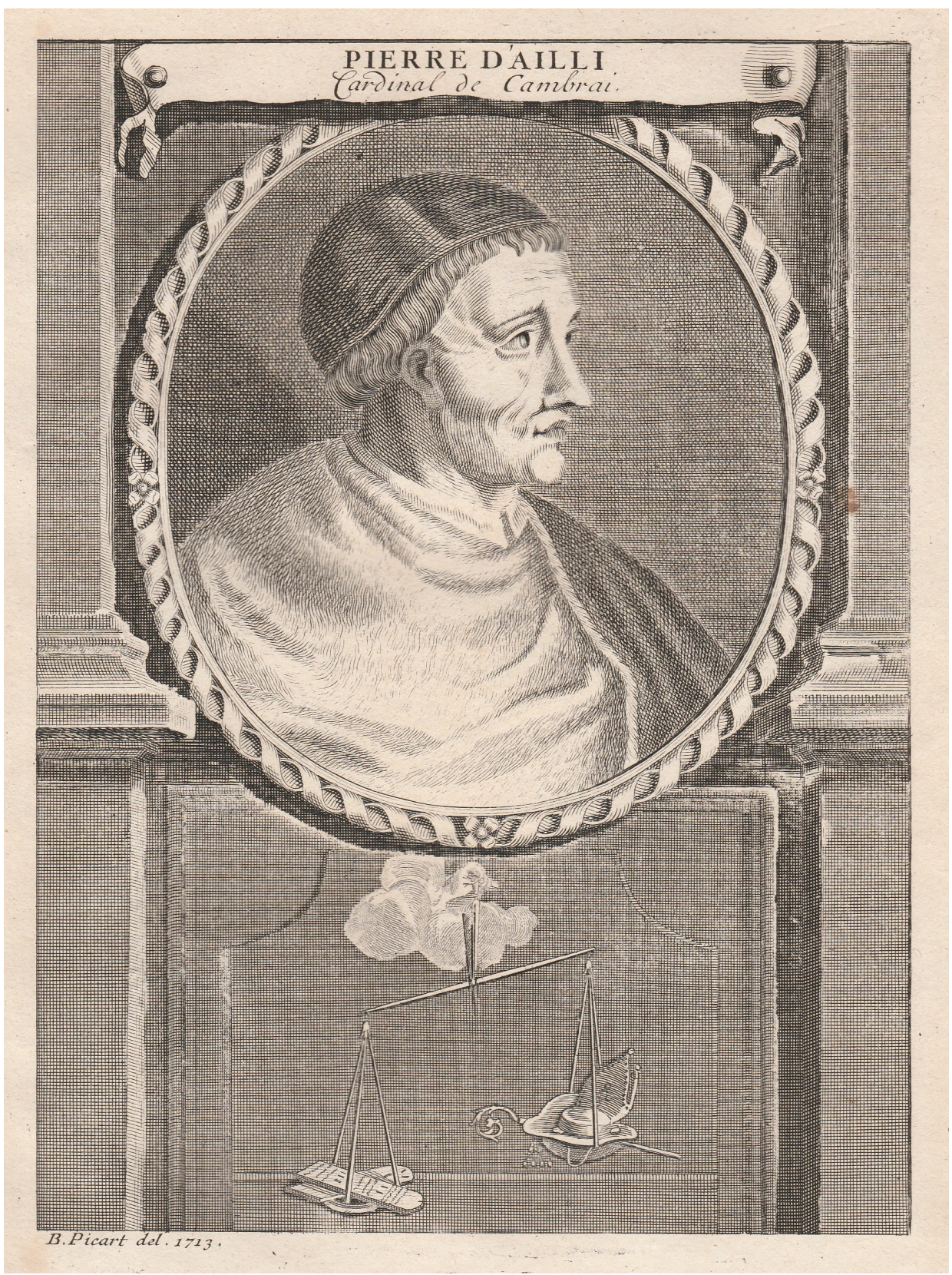




\subsection{Napredek v navigaciji, kartografiji in poznavanju sveta}

V visokem srednjem veku je prišlo do več izboljšav na področju navigacije in pomorstva. Nekatere od njih so izhajale z univerze v Palermu, kjer je s podporo normanskega kralja Sicilije Rogerja II. arabski geograf Al Idrisi med drugim poučeval tudi plovbo po odprtem morju. Kot pripomoček pri orientaciji na morju so začeli uporabljati magnetni kompas. Prva omemba kompasa v krščanskem delu Evrope je s konca 12. stoletja, do 15. stoletja je prišel v splošno uporabo in postal nepogrešljiv pripomoček za plovbo po odprtem morju. $\mathrm{V}$ tem času so izboljšali tudi astrolab, napravo za natančnejše določanje višine Severnice nad horizontom in s tem geografske širine.

Konec 14. stoletja je prišlo do opaznega napredka pri izdelavi kart. Za potrebe pomorstva so začeli izdelovati t. i. portolane (lat. portus, it. porto - pristanišče). Prvi so bili izdelani okoli leta 1300, v naslednjih stoletjih so postali nepogrešljiv del opreme kapitanov. $\mathrm{V}$ portolanih je bila namesto geografske koordinatne mreže vrisana mreža križajočih se linij, ki so izhajale iz več središč in kazale smer plovbe iz ključnih točk. Linije so sovpadale z 8 ali 16 smermi neba. Kot pomoč pri plovbi so mornarji te linije uskladili s smermi neba na kompasu. Zaradi uporabe kompasa so začeli iz praktičnih razlogov karte risati tako, da je bil sever zgoraj (Matvejević, 2008).

Slika 6: Portolan Jadranskega morja izolskega kartografa in horografa Pietra Coppe (1469 ali 1470-1555 ali 1556) (Pietrus Coppus Fecit, 2001, str. 57).

Figure 6: Portolan chart of the Adritic Sea by cartographer and chorograph Pietro Coppo of Izola (1469 or 1470-1555 or 1556) (Pietrus Coppus Fecit, 2001, p. 57).

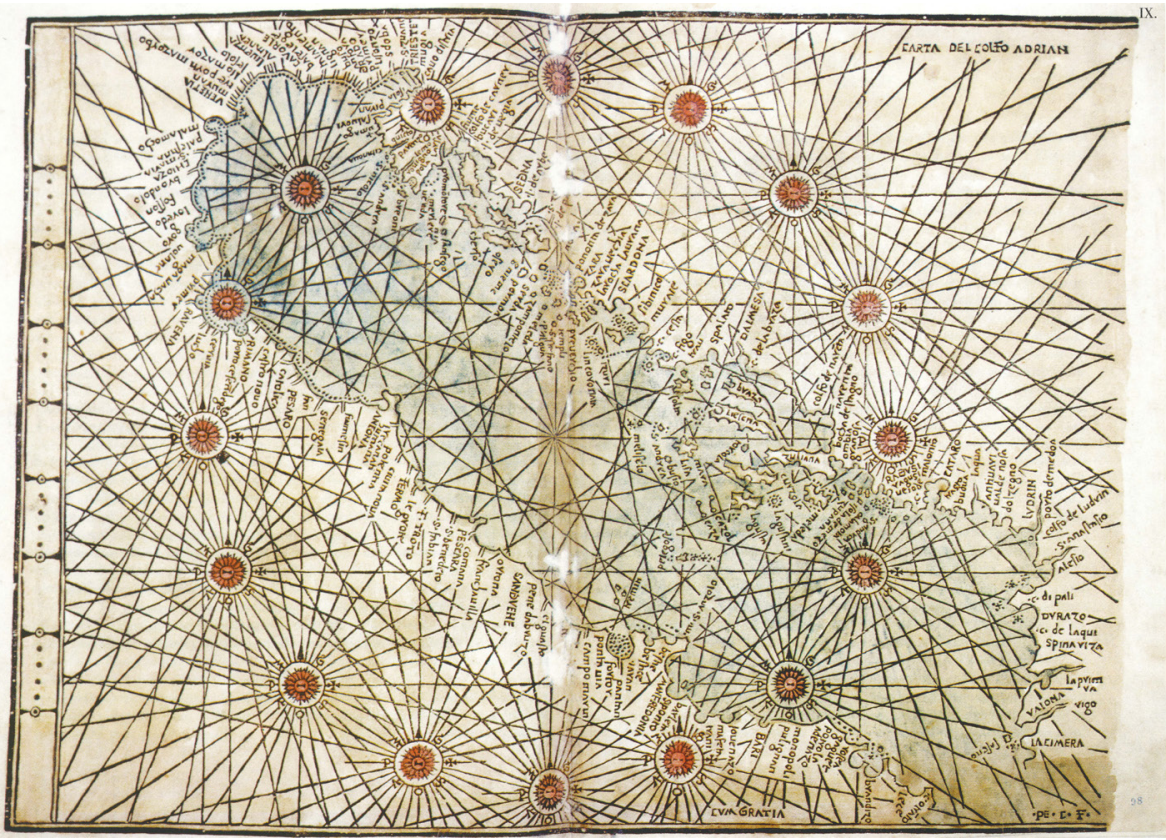


Leta 1375 so na osnovi velikega števila portolanov izdelali zelo znano Katalonsko karto sveta (tudi Katalonski atlas). Na njej je prikazana tudi zahodna obala Afrike južno od Rta Bajador, ki ga evropski morjeplovci v tem času še niso dosegli. Prikazuje tudi Vzhodno in Jugovzhodno Azijo, osnova za ta prikaz so bila poročila Marca Pola. Katalonska karta sveta je prvi zemljevid, na katerem sta verodostojno prikazana Cejlon in Dekanski polotok.

V 14. stoletju je začelo prihajati do razkoraka med poznavanjem sveta in njegovim kartografskim upodabljanjem. Na eni strani so delovali učenjaki v samostanih, ki so informacije večinoma črpali iz literature, na drugi praktiki, ki so zemljevide izdelovali za trgovce in pomorščake, ki so bili hkrati odličen vir novih informacij o svetu. Sklepamo lahko, da praktični uporabniki geografskega znanja niso bili seznanjeni z razpravami, ki so potekale za samostanskimi zidovi, do učenjakov za njimi pa so zelo počasi prodirale novice o svetu. Do združitve znanstvenih in pomorskih del je po mnenju Matvejevića (2008) prišlo v Španiji v času velikih odkritij; primer je delo Suma de geographia Martína Hernándeza de Encisa iz leta 1519, v katerem v španščini poroča o odkritjih v Novem svetu.

Osrednja osebnost, ki je krščansko Evropo seznanila z deželami na Daljnem vzhodu, je bil Marco Polo (1254-1324). Družina Polo iz Benetk je bila ena od trgovskih družin, ki je kljub temu, da so bile poti proti vzhodu blokirane, vzdrževala stike s Kitajsko po poteh severneje od ozemelj pod nadzorom muslimanov. Teh poti so se ob trgovcih posluževali tudi misijonarji. Leta 1271, ko je bil Marco star 17 let, je šel z očetom in stricem na pot proti Kitajski. Brata Polo sta pred tem obiskala Kitajsko med letoma 1260 in 1269. Potovanje je trajalo štiri leta, družina Polo je na Kitajskem ostala 17 let. Marco je kot ambasador kitajskega dvora služboval v različnih kitajskih pokrajinah in ga zastopal v upravnih zadevah ter podrobno spoznal deželo in njeno kulturo. Leta 1292 je mongolski vladar Kitajske in večine Daljnega vzhoda dovolil družini Polo vrnitev v domovino, proti kateri so odpluli s 14 ladjami in 600 možmi iz južne Kitajske, preko Jave, Sumatre, Cejlona in južne Indije do Hormuza v Perzijskem zalivu. Večino ladij in posadke so na poti izgubili. Od tam je do Črnega morja Polo potoval po kopnem, nato po morju do Benetk, kamor so Polovi prispeli po 25-letni odsotnosti leta 1295.

Po vrnitvi v domovino je Marco Polo pogosto pripovedoval o svojih potovanjih in nenavadnih ter čudnih stvareh, ki jih je doživel v neznanih deželah. Ogromnost razdalj in velika števila, ki jih je omenjal, so bila vzrok, da je dobil vzdevek »milijonar«, njegova hiša pa »dvor milijonov«. Kljub vabilom, da svoja potovanja opiše, je do zapisa prišlo šele, ko je bil kot genovski ujetnik v ječi. Pripoved, tudi na podlagi zapisov, ki jih je naredil na Kitajskem, je zapisal njegov sojetnik, pisatelj Rustichello da Pisi v knjigi Il Millione (Milijon). Knjiga se je s prepisovanjem kmalu razširila po vsej Evropi in postala znana kot Potovanja Marca Pola (slovenska izdaja: Potovanja Marka Pola, 1954). Vsebina knjige je bila za takratno Evropo zanimiva, vendar zelo nenavadna, zato ji niso verjeli in so jo imeli za plod domišljije.

Potopis Marca Pola je dal leta 1559 natisniti Giovanni Battista Ramusio. Do takrat so začeli tudi na podlagi poročil drugih popotnikov in raziskovalcev vsebini knjige počasi verjeti. Ker so v visokem srednjem veku potopis Marca Pola zavračali, ni imel izrazitejšega vpliva na tedanje geografske predstave o svetu in na izdelovanje zemljevidov. Danes 
štejemo njegovo delo za enega pomembnejših zapisov o velikih geografskih potovanjih, saj je prvi opisal srednjeazijske puščave in življenje ljudstev na Kitajskem in Tibetu, prvi je omenjal skrivnostno Sibirijo, govoril o psih, ki vlečejo sani, poročal o strašni indijski vročini in opisal kamen, ki se drobi in gori (premog) itd. Upošteval ga je tudi Krištof Kolumb, ki je imel kopijo knjige, v katero je pisal svoje pripombe (Martin, James, 1993). Ker Polo ni imel geografskega predznanja, se ni spuščal v takrat aktualne akademske razprave (npr. ali je ob ekvatorju prevroče za življenje), tudi ni razpravljal o obsegu Zemlje, ni poznal trditve, da je Indijski ocean zaprto morje, ni dokazov, da je razmišljal o geografski širini in dolžini krajev, ki jih je obiskal. V njegovem potopisu tudi ni komentarjev predhodnih geografskih del.

Slika 7: Marco Polo po sliki holandskega slikarja Jana van Grevenbroecka (po razglednici, zbirka: D. Ogrin).

Figure 7: Marco Polo, after the image by the Dutch painter Jan van Grevenbroeck (from a picture postcard; collection: D. Ogrin).

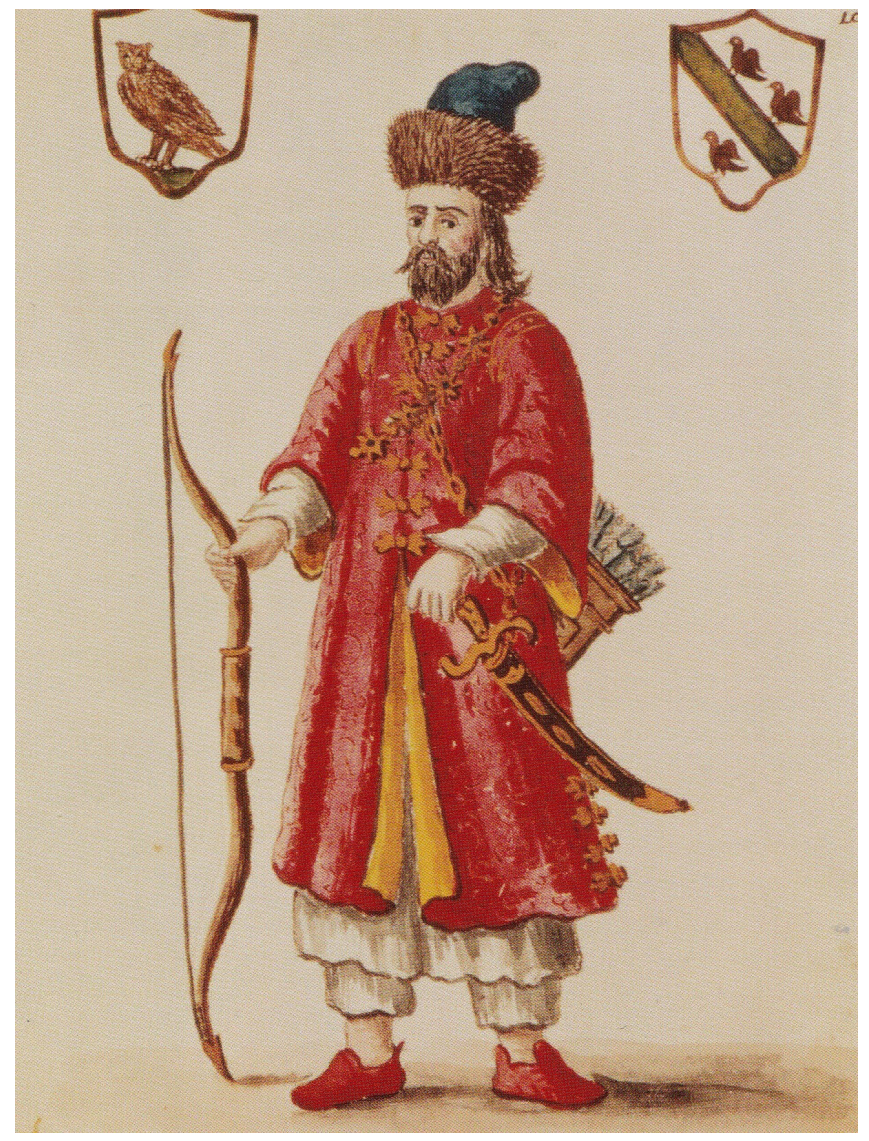


Pri širjenju geografskega horizonta proti vzhodu in severu so odigrali v visokem srednjem veku pomembno vlogo Rusi. Nestorjev letopis iz obdobja 1114-1116 vsebuje opise krajev in dogodkov v Vzhodni in Severni Evropi ter Aziji, domnevno na temelju normanskih informacij tudi krajev v Zahodni Evropi. Na osnovi potovanj, ki so bila versko, trgovsko in deloma tudi znanstveno motivirana, so nastali spisi potopisnega značaja, imenovani hodženija, V njih so opisana potovanja v Srednjo Azijo, jugozahodno Sibirijo, Indijo, Kitajsko in Sveto deželo. Posebno vlogo je pri raziskovanju težko dostopnih in neznanih pokrajin na severu in severovzhodu ter plovbah ob obalah Skandinavije in Sibirije odigral veliki ruski trgovski center Novgorod. Na žalost se nam podrobni podatki o tem niso ohranili, poročal pa je o teh potovanjih in odkritjih Vipavčan Žiga (Sigismund) Herberstein v svojem delu Rerum moscoviticarum commentarii iz leta 1549 (slovenski prevod: Moskovski zapiski, Herberstein, 1951; 2001). To kaže, da so imeli Rusi pri odkrivanju dežel dolgo tradicijo in bili zelo aktivni, še preden so do njih prispela prva poročila o velikih geografskih odkritjih na zahodu (Ilešič, 1950).

\section{SKLEP}

Srednji vek v razvoju geografije ne predstavlja enotnega obdobja, tudi ne mračnega, kakor se ga pogosto označuje. Oznaka 'mračno' v določeni meri velja le za zgodnji srednji vek v krščanskem delu Evrope, kjer Cerkev sprva ni kazala večjega posluha za znanstvena dognanja in je antična geografska tradicija večinoma šla v pozabo ter $\mathrm{z}$ njo tudi termin geografija.

Drugače je bilo v islamskem svetu, ki je imel nekaj več posluha za znanost in je vložil veliko napora $v$ vzpostavitev stika $\mathrm{z}$ antičnimi dognanji in dognanji drugih razvitih civilizacij. Na prevzetih temeljih so zgradili lastno znanstveno in geografsko tradicijo. Po zaslugi islamske civilizacije in tudi Bizantincev, pri katerih je antična znanost tudi deloma preživela, je v visokem srednjem veku, ko je cerkveni dogmatizem popustil in je tudi Cerkev začela kazati večje zanimanje za znanost, prišlo do renesanse antičnih spoznanj in gledanja na svet. Postavljeni so bili temelji za nov znanstveni in družbeni razvoj v naslednjih stoletjih.

Nosilec novih idej in napredka je bilo meščanstvo, ki je v ospredje postavljalo človekove vrednote in je znanje potrebovalo za gospodarski napredek. S področja geografije so postale cenjene natančne karte kot pripomoček pri plovbi in informacije o deželah in morjih, s katerimi so trgovali in po katerih so pluli. Znotraj starega in utečenega se je porajalo novo. Stanje geografije pred začetkom velikih geografskih odkritij v 15. in 16 . stoletju nazorno ilustrirajo Ilešičeve besede: »Vsa ta geografska in kartografska renesansa od 12. do 15. stoletja je v znaku silne neenakomernosti, neskladnosti v razvoju. Na eni strani meniške karte, na drugi portulanske, na eni strani dobro poznavanje novih odkritij na zapadu in vzhodu, drugje v tem pogledu absolutne vrzeli, ki pričajo, kako težko je v tedanji dobi brez hitrih prometnih sredstev in brez tiskanih knjig novo znanje prodiralo $\mathrm{v}$ svet« (Ilešič, 1950, str. 26). 


\section{Literatura in viri}

Burke, P., 2016. Where Geography Came From. V: Agnew J. A., Duncan J. S. (ur.). The Wiley Blackwell Companion to Human Geography, Chichester, Wiley Blackwell, str. $12-22$.

Cresswell, T., 2013. Geographic Thought: a Critical Introduction. Chichester, Wiley-Blackwell, 290 str.

Herberstein, Ž., 1951. Moskovski zapiski. Ljubljana, Državna založba Slovenije, 277 str. Herberstein, Ž., 2001. Moskovski zapiski. Ljubljana, Slovenska matica, 290 str.

Holt-Jensen, A., 2009. Geography, its History and Concepts: A Student Guide. Los Angeles, Sage, 264 str.

Hriberšek, M., 2013. Po Plinijevem nebu in zemlji. Komentar h knjigam 1-6 Plinijevega Naravoslovja. Ljubljana, Založba ZRC, 806 str.

Ibn Battuta. 2011. URL: http://content.time.com/time/specials/packages/article/0,28804,2084273_2084272_2084270,00.html (citirano 3.9. 2018).

Ibn Battuta, 2016. Veliko popotovanje. Ljubljana, Založba FDV, 215 str.

Ilešič, S., 1950. Zgodovina geografije [Tipkopis]. Ljubljana, Univerza v Ljubljani, Prirodoslovno matematična fakulteta, Oddelek za geografijo, 80 str.

Martin, G. J., James, P. E., 1993. All Possible Worlds: a History of Geographical Ideas. New York, John Wiley and Sons, 585 str.

Matvejević, P., 2008. Mediteranski brevir. Ljubljana, Založba V.B.Z., 243 str.

Millerjeva rekonstrukcija karte sveta Pomponiusa Mele iz leta 1898, 2016. URL: https:// upload.wikimedia.org/wikipedia/commons/b/bd/Karte_Pomponius_Mela.jpg (citirano 12. 8. 2018).

Nikolić, S. M., 1977. Uvod u geografiju - istorija geografije i geografskih otkrića. Beograd, Naučna knjiga, 316 str.

Ogrin, D., 2005. Spreminjanje podnebja v holocenu. Geografski vestnik, 77, 1, str. 57-66.

O-T karta sveta. 2018. URL: https://en.wikipedia.org/wiki/T_and_O_map\#/media/File:Radkarte_MKL1888.png (citirano 12.8.2018).

Pietrus Coppus Fecit: De summa totius orbis (razstavni katalog), 2001. Piran, Galerija Hermana Pečariča, 60 str.

Potovanja Marka Pola. 1954. Ljubljana, Mladinska knjiga, 244 str.

Rana, L., 2008. Geographical Thought - A Systematic Record of Evolution. New Delhi, Concept Publishing Company, 495 str.

Svetovna zgodovina od začetkov do danes. 1976. Ljubljana, Cankarjeva založba, 687 str.

Travels of Ibn Battuta, WorldMap. 2015. URL: https://www.reddit.com/r/MapPorn/ comments/4nksvv/the_voyages_of_ibn_battuta_the_most_well_traveled (citirano 20. 8. 2018).

Vresk, M., 1997. Uvod u geografiju, razvoj, struktura, metodologija. Zagreb, Školska knjiga, 304 str.

Vrišer, I., 2002. Uvod v geografijo. Ljubljana, Oddelek za geografijo Filozofske fakultete Univerze v Ljubljani, 414 str. 


\section{DEVELOPMENT OF GEOGRAPHY IN THE MIDDLE AGES}

\section{Summary}

Social and economic situation changed in the Middle Ages, particularly in Europe. Historically, the Middle Ages began with the fall of the Western Roman Empire at the end of the $5^{\text {th }}$ century and lasted in Europe until the end of the $15^{\text {th }}$ century, more precisely until the discovery of America. In the Early Middle Ages, that is until around the year 1100, Christianity exerted profound influence on the social, economic and cultural development and way of thinking. It is characteristic of that time that the majority of cultural and scientific views of Classical Antiquity fell into oblivion; in geography they were replaced by uncritical cosmographies, mostly based on sacred writings. Travels and researches were very few because of political instability. Most of the intellectual life was going on behind the walls of monasteries, where scholars collected information from a variety of written sources, mainly Latin, and reconciled them with the facts as presented in the Bible. The contents which did not agree with the Bible were ignored. Classical ideas about the world were transformed to fit the Church doctrine. The Earth was understood as a disk, with Jerusalem in the centre. The Classical tradition of map-making declined. The maps that were drawn were indeed aesthetic, but unprofessional. The most widely spread type of maps of that time were represented by the so-called orbis-terrarum or T-and-O (or O-T or T-O) maps.

After the fall of the Western Roman Empire, the geographical horizon was drastically reduced. People were mostly familiar only with the areas and places in their immediate vicinity. At that time, the Christian part of Europe had inadequate ideas of the world, with a lot of vagueness about the size of the world and distances between places. While Europe was stagnating intellectually, remarkable progress was made by the Arab world which accepted the Classical knowledge and upgraded it. The rise of Arab scientific centres meant the end of the recession of science and the re-development of scientific approaches in geography.

The contribution of Arab scholars to the development of geography was huge and reaches to various fields, from physical, human and regional geography to cartography. They took the basic astronomic and mathematical-geographic knowledge from the ancient Greeks, in the first place from the works by Aristotle and Ptolemy. In the field of physical geography, Arab geography made great progress in the knowledge of geomorphological, oceanographic and, in particular, climate phenomena and processes. Human-geography contents can be found especially in the works by Ibn Khaldun, who is regarded as a forerunner of modern historiography, sociology, economy, and demography. Very great is Arab contribution to the knowledge of the world. Outstanding are the works by Al-Idrisi and Ibn Battuta. Al-Idrisi's book Al-Kitab al-Rujari (Roger's Book) is a geographic encyclopaedia of the world known at that time. Ibn Battuta is considered one of the greatest travellers of all time; he travelled the major part of south and central Asia and visited China sixty years before Marco Polo. He travelled the Saharan Africa, sailed the Indian Ocean, and along the eastern coast of Africa he reached the geodetic latitude of $10^{\circ} \mathrm{S}$.

In the High Middle Ages the authority of the Church over science slowly began to wane. It was shattered by scholars, also those inside the Church itself, who were brave enough to 
put scientific arguments against the arguments of Church authorities. In the Middle Ages, Ptolemy was the principal authority in astronomic knowledge. His work that explains the influence of celestial bodies on the humans was translated from Arabian into Latin in 1138, and Almagest, the great work on astronomy, in 1175. Under the influence of the latter study the geocentric explanation of the universe was accepted for several centuries.

Towards the end of the Middle Ages, the cultural movements of Humanism and the Renaissance were of great importance for the development of science, including geography. The Humanists modelled their activities on Classical Antiquity, so the interest in the culture and science of the old Greeks and Romans was steadily revived. The contact with the Antiquity was possible also thanks to the Arabs who had carried on Classical scientific traditions. Relevant for the development of geography were the years 1410, when copies of Geography by Ptolemy were translated into Latin, and 1450, when Geography by Strabo was translated. The knowledge about the world and universe, contained in these two works, was one of the bases of Humanism. Translations of Ptolemy's and Strabo's works increased the interest in geography and, in turn, geographical knowledge contributed considerably to the discovery and economic exploitation of new and less known territories, which was led by the rising class of bourgeoisie, merchants in particular. The bourgeoisie needed geographical knowledge to foster trade, travels and voyages, and to learn about the countries with which they had established trade, and to maintain control over the colonies. Improved variants of Ptolemy's maps began to emerge, later also maps with improved map projections and coordinate system.

A great influence on geographic discoveries that started in the second half of the $15^{\text {th }}$ century was also exerted by the cosmography Tractatus de imagine mundi by Cardinal Pierre d'Ailly. The book is a quality compendium of the knowledge about the world in his time and is one of the first to include the findings from the Latin translation of Ptolemy's Geography.

In the High Middle Ages, several improvements were introduced in the fields of navigation, seafaring and cartography. Magnetic compass began to be used as an aid in the orientation on the sea, the astrolabe was also improved, which rendered possible to determine the latitude more accurately. For the needs of seafaring the so-called portolan charts were made, i.e. maps with precisely drawn coastlines and ports and a compass network for easier navigation.

Marco Polo was the central figure to acquaint the Christian Europe with the lands of the Far East. Because in the High Middle Ages his travel journal was rejected, it did not influence the geographic ideas of the world and map-making of the time as much as we might expect. Nowadays, however, Polo's work is considered one of the more important records of great geographic travels, for he was the first to describe the deserts of Persia and the life of the peoples of China and Tibet, the first to mention the mysterious Siberia, or reported on the fierce heat in India, etc. 